University of Nebraska - Lincoln

DigitalCommons@University of Nebraska - Lincoln

Agronomy \& Horticulture - Faculty Publications

Agronomy and Horticulture Department

2018

\title{
Improving fertilizer recommendations for Nepalese farmers with the help of soil-testing mobile van
}

\author{
Sunil Pandey \\ Soil Management Directorate, Hariharbhawan, Lalitpur, Nepal \\ Netra Prasad Bhatta \\ Soil Management Directorate, Hariharbhawan, Lalitpur, Nepal \\ Prakash Paudel \\ Soil Management Directorate, Hariharbhawan, Lalitpur, Nepal \\ Rajan Pariyar \\ Soil Management Directorate, Hariharbhawan, Lalitpur, Nepal \\ Kiran Hari Maskey \\ Soil Management Directorate, Hariharbhawan, Lalitpur, Nepal
}

See next page for additional authors

Follow this and additional works at: https://digitalcommons.unl.edu/agronomyfacpub

Part of the Agricultural Science Commons, Agriculture Commons, Agronomy and Crop Sciences Commons, Botany Commons, Horticulture Commons, Other Plant Sciences Commons, and the Plant Biology Commons

Pandey, Sunil; Bhatta, Netra Prasad; Paudel, Prakash; Pariyar, Rajan; Maskey, Kiran Hari; Khadka, Janardan; Thapa, Tuk Bahadur; Rijal, Balaram; and Panday, Dinesh, "Improving fertilizer recommendations for Nepalese farmers with the help of soil-testing mobile van" (2018). Agronomy \& Horticulture -- Faculty Publications. 1180.

https://digitalcommons.unl.edu/agronomyfacpub/1180

This Article is brought to you for free and open access by the Agronomy and Horticulture Department at DigitalCommons@University of Nebraska - Lincoln. It has been accepted for inclusion in Agronomy \& Horticulture -Faculty Publications by an authorized administrator of DigitalCommons@University of Nebraska - Lincoln. 


\section{Authors}

Sunil Pandey, Netra Prasad Bhatta, Prakash Paudel, Rajan Pariyar, Kiran Hari Maskey, Janardan Khadka, Tuk Bahadur Thapa, Balaram Rijal, and Dinesh Panday 


\title{
Improving fertilizer recommendations for Nepalese farmers with the help of soil-testing mobile van
}

\author{
Sunil Pandey, ${ }^{1}$ Netra Prasad Bhatta, ${ }^{1}$ Prakash Paudel, ${ }^{1}$ \\ Rajan Pariyar, ${ }^{1}$ Kiran Hari Maskey, ${ }^{1}$ Janardan Khadka, ${ }^{1}$ \\ Tuk Bahadur Thapa, ${ }^{2}$ Balaram Rijal, ${ }^{1}$ and Dinesh Panday ${ }^{3}$
}

1 Soil Management Directorate, Hariharbhawan, Lalitpur, Nepal

2 Regional Soil Testing Laboratory, Pokhara, Kaski, Nepal

3 Department of Agronomy and Horticulture, University of Nebraska-Lincoln, Lincoln, Nebraska, USA

Corresponding author - Dinesh Panday, dinesh.panday@unl.edu, 178 Keim Hall, University of Nebraska-Lincoln, Lincoln, NE-68583-0915, USA.

Sunil Pandey and Dinesh Panday contributed equally to this work.

ORCID - Dinesh Panday oooo-ooo1-8452-3797

\begin{abstract}
Smallholder farmers dominate agriculture in Nepal. These farmers have poor knowledge about agriculture and lack of support for soil management and integrated plant-nutrient systems. Focusing on the importance and need for soil-fertility management, a soil-testing mobile van program has recently been introduced in Nepal by Soil Management Directorate, Hariharbhawan. With the introduction of the mobile lab, famers can get their soil tested for nutrient deficiencies and fertilizer requirements at their doorsteps. Using mobile lab, spatial distributions of chemical properties, including $\mathrm{pH}$, organic matter $(\mathrm{OM})$, total nitrogen $(\mathrm{N})$, available phosphorus (as $\mathrm{P}_{2} \mathrm{O}_{5}$ ), and available potassium (as $\mathrm{K}_{2} \mathrm{O}$ ) were examined in soil samples taken from the o to $15 \mathrm{~cm}$ depth from selected agricultural fields in eight different districts in the mid-hills and Terai regions of Nepal. Tests conducted on 1,479 soil samples in the soil-testing mobile van revealed the following: the mean soil OM ranged from 0.01 to $1.77 \%$; total $\mathrm{N}$ content ranged from 0.01 to $0.08 \%$; mean available $\mathrm{P}_{2} \mathrm{O}_{5}$ ranged from 16.47 to $197.82 \mathrm{~kg} \mathrm{ha}^{-1}$; and mean available $\mathrm{K}_{2} \mathrm{O}$
\end{abstract}


ranged from 84.3 to $422.57 \mathrm{~kg} \mathrm{ha}^{-1}$. For each crop to be grown, farmers were provided with individual soil health reports and fertilizer recommendations (rate, amount, and type). This program not only allows scientists and farmers to work closely and share information but also serves as a model for the nation to successfully transfer technology for improving soil health and sustainability.

Keywords: Integrated plant nutrient system, mobile lab, smallholder farmers, soil fertility, sustainability

\section{Introduction}

Nepal can be broadly divided into three ecological zones: Terai (plain), midhills, and high-hills. Because of the advantages of tropical and sub-tropical climates in the Terai region, cereal crops can be extensively grown. The main crops grown include rice (Oryza sativa L.), wheat (Triticum aestivum L.), maize (Zea mays L.), potato (Solanum tuberosum L.), sugarcane (Saccharum spp.), and various pulses. Cash crops, such as tea (Camellia sinensis), coffee (Coffee arabica), ginger (Zingiber officinale), and many kinds of vegetables, are the most dominant in mid-hills. The high-hills region is most suitable for livestock production; soils in these areas being sandy, dry, and highly prone to wind erosion are unsuitable for crop production. In an ecological context, the country has great prospects for agricultural diversification (Panday 2012; Paudel et al. 2014; Sharma 2001).

Agriculture in Nepal is still largely subsistence in nature and dominated by smallholder farmers and mixed cropping systems. Many studies have shown that a decline in soil fertility across the country is a key factor that constrains the productivity of most crops and farming systems (Balla et al. 2014; Rijal 2001; Schreier, Brown, and Shah 1995). There are a variety of other causes that are responsible for the stagnant productivity; for example, climatic variations (Panday 2012), changing farming practices (Ghimire and Panday 2017; Paudel et al. 2014), and soil erosion (Maharjan and Joshi 2013). The national average for the use of chemical fertilizer has increased dramatically from $16.7 \mathrm{~kg} \mathrm{ha}^{-1}$ in 2002 to $67.4 \mathrm{~kg} \mathrm{ha}^{-1}$ in 2014 (WBG 2017). However, chemical fertilizer use in Nepal is still relatively low compared with other Asian countries. Farmers use 2.5 to $3 \mathrm{t} \mathrm{ha}^{-1}$ of organic manure annually for soil-fertility management (NARC 2013).

The Department of Agriculture under the Ministry of Agricultural Development (MOAD) in Nepal implements many programs to focus on the importance of and need for soil-fertility management. Such programs include promotion of organic manure and compost, green manuring, balanced use of chemical fertilizers, soil-testing services, farmers' field school regarding 
integrated plant-nutrient system, distribution of rhizobium inoculation packets, and other trainings and demonstrations. Of these, soil-testing service is one of the high priority programs. Soil-testing is an important diagnostic tool to assess nutrient sufficiency in plants. One of the objectives of soil sampling is to distinguish nutrient-deficient areas from nutrient-sufficient areas (Marx, Hart, and Stevens 1999). Fertilizer recommendations are only as good as the accuracy of the soil tests on which they are based (Rosen, Bierman, and Eliason 2008). There are many soil-testing laboratories in $\mathrm{Ne}$ pal, including those operated by government and nongovernmental organizations. However, farmers must travel to these labs to get their soil samples analyzed. This can be very difficult because the laboratories are located in the district headquarters or in the country's capital city.

\section{Soil-testing mobile van}

A soil-testing mobile van (also called mobile lab) was introduced in Nepal in 2014. It was gifted to the MOAD, Nepal, by Paradeep Phosphate Limited of Odisha, India. With the introduction of the mobile lab, famers will now be able to have their soil samples tested for nutrient deficiencies and fertilizer requirements at their doorsteps. Such programs have recently been introduced in other countries as well. For example, in India, mobile labs began functioning in 2012 under the Manav Vikas Mission mobile soil-testing laboratory program, and 'Soilcares' initiative implemented mobile labs in Kenya in 2014.

The mobile soil-testing labs are much like the stationary laboratories with regard to staff, type of equipment, facilities, and soil-testing methods. In such labs, all the major soil-testing equipment, including spectrophotometer, flame photometer, colorimeter, $\mathrm{pH}$ meter, electric shaker, magnetic stirrer, weighing machine, and any necessary glass wares, are available. In addition, information about soil-management practices is presented to farmers in the form of documentaries and films.

Generally, a mobile soil camp stays in a place for less than a week. However, farmers' demand for soil-testing is quite high and the capacity of a soiltesting mobile van is 40 samples per day. Farmers are instructed on how to take soil samples through documentaries and multimedia on the first day of the camp. Then, the farmers bring their soil samples to be tested. The samples are prepared on the spot using a grinder and sieve. The fine soil, after sieving, is used to analyze $\mathrm{pH}$, organic matter (OM), total nitrogen $(\mathrm{N})$, available phosphorus (as $\mathrm{P}_{2} \mathrm{O}_{5}$ ), and available potassium (as $\mathrm{K}_{2} \mathrm{O}$ ).

On the final day, farmers are provided with soil-health reports and recommendations. These reports include both quantitative and qualitative results (i.e., very low, low, medium, high, and very high). Thus, farmers get to know the nutrient status of their fields and can follow the suggested 
recommendations. If the recommended soil-management practices are followed properly, soil-fertility can be improved. The objective of this investigation was to explain the status of soil-fertility programs, introduce soiltesting mobile van, and provide information on soil-testing success from eight different districts for four different commodities (rice, maize, potato, and vegetables). Recommendations for fertilizers and soil amendments in Nepal are described.

\section{Methodology}

\section{Soil sampling locations}

Nepal is split into 75 districts and has four seasons: pre-monsoon (March to May), monsoon (June to September), post-monsoon (October to November), and winter (December to February). Monsoon is the main source of precipitation, which accounts for $85 \%$ of total annual rainfall of $1800 \mathrm{~mm}$, and the remainder $15 \%$ occurs in winter (Panday 2012).

Fragmentation of arable land being a major barrier for agriculture commercialization and mechanization in the country, the MOAD has classified land-holdings as pockets (at least 10 ha of land), blocks (100 ha of land), zones (500 ha of land), and superzones (1000 ha of land) to address the issue of fragmentation of arable land through the Prime Minister Agriculture Modernization Project (PMAMP) in the fiscal budget 2016-2017. The government has planned for further development of large-sized agricultural production areas, commercial agricultural areas, agri-processing centers, and agri-industrial areas for pockets, blocks, zones, and superzones, respectively.

In the first phase of the soil-testing mobile van program, Soil Management Directorate (SMD) of MOAD has selected one block, two zones, and two superzones to support farmers through PMAMP. The details of the categories, commodities, and districts included rural municipality (RM), municipality (M), or metropolitan (Mp) and the number of samples for the first phase of the soil-testing mobile van program are given in Table 1. Study locations are shown in Figure 1. The study was carried out from August 2016 to April 2017.

\section{Sample collection and analyses}

The interested farmers in the selected location were trained by the extension workers to collect soil samples prior to conducting soil analyses at the mobile van facility. In addition, soil analysis team used multimedia and films

to demonstrate soil sampling methods to farmers on the first day of the 
Table 1. Commodities, sampling locations and number of sample collections during soiltesting mobile van program in Nepal.

\begin{tabular}{|c|c|c|c|c|c|}
\hline Category & Commodity & $\begin{array}{l}\text { Ecological } \\
\text { zone }\end{array}$ & District & Location area & $\begin{array}{r}\text { Number of } \\
\text { samples }\end{array}$ \\
\hline Superzone & Rice & Terai & Jhapa & Kechankebal $\mathrm{RM}^{\dagger}$ & 219 \\
\hline \multirow[t]{4}{*}{ Block } & \multirow[t]{4}{*}{ Rice } & Terai & Nawalparasi & Sunwal $M^{\ddagger}$ & 86 \\
\hline & & Terai & Morang & Sundar Haraincha $\mathrm{M}^{\ddagger}$ & 40 \\
\hline & & Terai & Saptari & Rupani $\mathrm{RM}^{\dagger}$ & 40 \\
\hline & & Terai & Sunsari & Inaruwa $\mathrm{M}^{\ddagger}$ & 40 \\
\hline Superzone & Potato & Mid-hills & Kavreplanchowk & Banepa $\mathrm{M}^{\ddagger}$ & 219 \\
\hline \multirow[t]{5}{*}{ Zone } & Maize & Mid-hills & Dhading & Nilkantha $\mathrm{M}^{\ddagger}$ & 201 \\
\hline & \multirow[t]{4}{*}{ Vegetable } & Mid-hills & Dhading & Benighat Rarang $\mathrm{RM}^{\dagger}$ & 143 \\
\hline & & & & Gajuri RM ${ }^{\dagger}$ & 109 \\
\hline & & & & Dhunibesi $\mathrm{M}^{\ddagger}$ & 101 \\
\hline & & Terai & Chitwan & Bharatpur $\mathrm{Mp}^{\S}$ & 241 \\
\hline Total $=$ & & & & & 1479 \\
\hline
\end{tabular}

† Rural Municipality

‡ Municipality

$\S$ Metropolitan
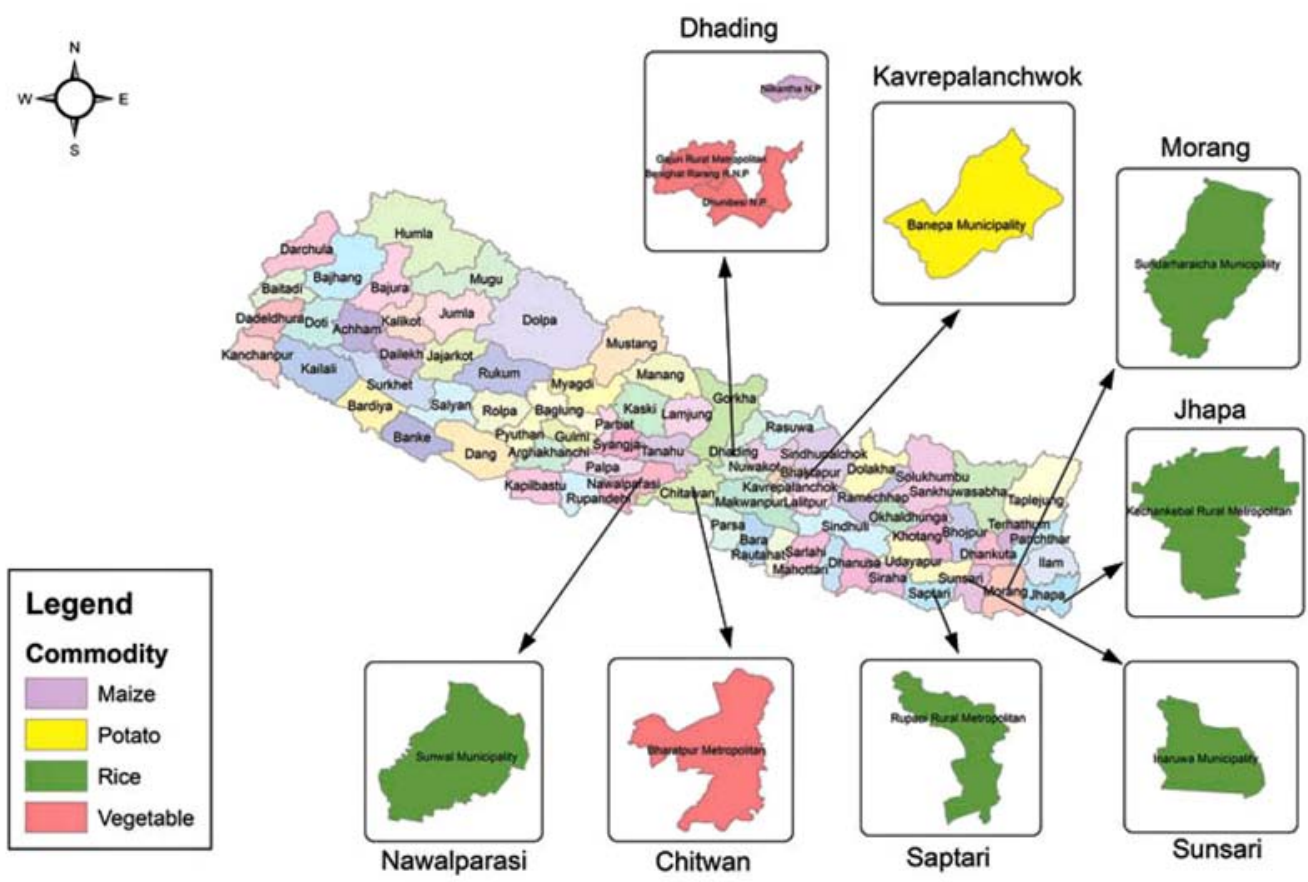

Chitwan

Saptari

Sunsari

Figure 1. Locations of soil sample collection. 
soil-testing camp. To maintain sample uniformity, farmers were encouraged to bring samples from their own topsoil layer (o to $15 \mathrm{~cm}$ depth).

The soil chemical parameters tested and methods used are given in Table 2. In general, the sampling, processing, and analysis of the soil samples in the mobile lab were carried out with the same procedures and methods as used in a stationary lab. However, $\mathrm{N}$ was determined by multiplying the OM value with 0.05, under the assumption that OM contains 5\% N. Extractant used for available $\mathrm{P}_{2} \mathrm{O}_{5}$ was $\mathrm{NaHCO}_{3}$ and that for available $\mathrm{K}_{2} \mathrm{O}$ was $\mathrm{C}_{2} \mathrm{H}_{7} \mathrm{NO}_{2}$. Preparation of soil analysis reports and recommendations were also performed in a similar manner as in the case of a stationary laboratory and were made available to farmers at the camp site.

Table 2. Methods used for testing of soil chemical parameters in soil-testing mobile van in Nepal.

\begin{tabular}{ll} 
Test & Method \\
\hline $\mathrm{pH}$ & $1: 2$ soil water suspension (Jackson 1973) \\
Organic matter $(\mathrm{OM}, \%)$ & Walkely and Black (Walkley and Black 1934) \\
Total nitrogen $(\mathrm{N}, \%)$ & $\mathrm{OM} \times 0.05$ \\
Available phosphorus $\left(\mathrm{P}_{2} \mathrm{O}_{5}, \mathrm{~kg} \mathrm{ha}^{-1}\right)$ & Olsen's bicarbonate (Olsen et al. 1954) \\
Available potassium $\left(\mathrm{K}_{2} \mathrm{O}, \mathrm{kg} \mathrm{ha}^{-1}\right)$ & Flame photometry (Toth and Prince 1949)
\end{tabular}

\section{Data analysis}

Descriptive statistics (mean, standard deviation, and coefficient of variation) for soil parameters were computed using Statistix 10. Ratings for $\mathrm{pH}$ and nutrient values (OM, N, $\mathrm{P}_{2} \mathrm{O}_{5}$, and $\mathrm{K}_{2} \mathrm{O}$ ) based on standards recommended by Nepal Agricultural Research Council, Nepal (NARC 2013) and used by Soil Management Directorate are shown below:

pH: Highly acidic <4.5, Acidic $=4.5$ to 5.5 , Slightly acidic $=5.5$ to 6.5 , Neutral $=6.5$ to 7.5 , and Alkaline $>7.5$

OM: Very high $>10$, High $=5$ to 10, Medium $=2.5$ to 5, Low $=1$ to 2.5 , and Very low $<1$

$N$ : Very high $>0.4$, High $=0.2$ to 0.4 , Medium $=0.1$ to 0.2, Low $=0.05$ to 0.1 , and Very low $<0.05$

$P_{2} \mathrm{O}_{5}$ : Very high $>110$, High $=55$ to 110, Medium $=30$ to 55, Low $=10$ to 30, and Very low $<10$

$\mathrm{K}_{2} \mathrm{O}:$ Very high $>500$, High $=280$ to 500, Medium $=110$ to 280, Low $=55$ to 110 , and Very low $<55$ 
The nutrient index was determined via the following formula given by Ramamurthy and Bajaj (1969):

$$
\text { Nutrient index }(\mathrm{NI})=\left[\left(\mathrm{N}_{\mathrm{L}} \times 1\right)+\left(\mathrm{N}_{\mathrm{M}} \times 2\right)+\left(\mathrm{N}_{\mathrm{H}} \times 3\right)\right] / \mathrm{N}_{\mathrm{T}}
$$

where $\mathrm{N}_{\mathrm{L}}, \mathrm{N}_{\mathrm{M}}$, and $\mathrm{N}_{\mathrm{H}}$ are number of samples falling in low (low and very low), medium, and high (high and very high) classes of nutrient status, respectively; and $\mathrm{N}_{\mathrm{T}}$ is the total number of samples analyzed for a given area. The resulting NIs were characterized as low (<1.67), medium (1.67 to 2.33), and high (>2.33).

\section{Results and discussion}

Summary statistics and rating of soil chemical parameters

Table 3 contains summary statistics for soil chemical properties, including $\mathrm{pH}$, OM (\%), $\mathrm{N}(\%), \mathrm{P}_{2} \mathrm{O}_{5}\left(\mathrm{~kg} \mathrm{ha}^{-1}\right)$, and $\mathrm{K}_{2} \mathrm{O}\left(\mathrm{kg} \mathrm{ha}^{-1}\right)$, from different locations. Results showed that $\mathrm{pH}$ ranged from 5.2 (in Jhapa district, rice superzone) to 7.9 (in Saptari district, rice block). Of the 1,479 samples for $\mathrm{pH}, 164$ samples were alkaline, 544 samples were neutral, 566 samples were slightly acidic, 188 samples were acidic, and 17 samples were highly acidic (Table 4). Most of the soils in Nepal are acidic in nature because of the dominant parent material (such as sandstone, siltstone, quartzite, and shale), natural vegetation, and loss of major cations because of high precipitation (Ghimire and Bista 2016). Plant growth and most soil processes are favored by a specific soil pH range. Acidic soil, particularly subsurface soil, will restrict plant roots' access to water and nutrients (Gazey and Davies 2009). Our observation of higher acidity in the Jhapa district than in Saptari and Nawalparasi districts may be associated with the loss of basic cations during the monsoon season. Though, all three districts are in Terai region, eastern part of Nepal (i.e. Jhapa district) gets more precipitation than central (i.e. Saptari district), and western (i.e. Nawalparasi district) regions. Other possible influences would include the type and history of fertilizer application, crop residue management, and nutrient uptake and crop harvest without replenishing nutrient across time (Bremner and Mulvaney 1982).

Soil OM ranged from $0.24 \%$ (in Sunsari district, rice zone) to $1.81 \%$ (in Morang district, rice block). The competing use of crop residues as animal feed limits nutrient return to the soil, and the sparse vegetation and intensive cropping generally account for the reduction of OM in the soil. Soil OM not only plays a major role in soil-fertility by affecting physical and chemical properties, but it also controls soil-microbial activity by serving as a 
Table 3. Summary statistics for selected soil chemical parameters from soil-testing mobile van program in Nepal.

\begin{tabular}{|c|c|c|c|c|c|}
\hline & $p H$ & $O M^{\pi}$ & $N^{\#}$ & $\mathrm{P}_{2} \mathrm{O}_{5}^{++}$ & $K_{2} \mathrm{O}^{\ddagger \ddagger}$ \\
\hline \multicolumn{6}{|l|}{ Rice } \\
\hline \multicolumn{6}{|c|}{ Kechankebal $\mathrm{RM}^{\dagger}$ Jhapa $(\mathrm{n}=219)$} \\
\hline Mean & 5.2 & 0.71 & 0.04 & 51.22 & 157.82 \\
\hline SD & 0.4 & 0.38 & 0.02 & 60.51 & 118.74 \\
\hline CV (\%) & 7.7 & 54.76 & 54.76 & 108.74 & 76.67 \\
\hline \multicolumn{6}{|c|}{ Sunwal $\mathrm{M}^{\ddagger}$ Nawalparasi $(\mathrm{n}=86)$} \\
\hline Mean & 7 & 1.77 & 0.09 & 22.98 & 85.45 \\
\hline SD & 0.9 & 1.07 & 0.05 & 20.49 & 59.1 \\
\hline CV (\%) & 12.2 & 60.48 & 60.48 & 89.15 & 69.16 \\
\hline \multicolumn{6}{|c|}{ Sundari Haraincha $M^{\ddagger}$ Morang $(n=40)$} \\
\hline Mean & 6.9 & 1.81 & 0.09 & 56.2 & 84.3 \\
\hline SD & 0.5 & 0.62 & 0.03 & 29.53 & 41.15 \\
\hline CV (\%) & 7.5 & 34.33 & 34.33 & 52.55 & 48.81 \\
\hline \multicolumn{6}{|c|}{ Rupani $\mathrm{RM}^{\dagger}$ Saptari $(\mathrm{n}=40)$} \\
\hline Mean & 7.9 & 1.17 & 0.06 & 16.47 & 135.3 \\
\hline SD & 0.2 & 0.49 & 0.02 & 8.64 & 23.86 \\
\hline CV (\%) & 2 & 42.1 & 42.1 & 52.49 & 17.63 \\
\hline \multicolumn{6}{|c|}{ Inaruwa $\mathrm{M}^{\ddagger}$ Sunsari $(\mathrm{n}=40)$} \\
\hline Mean & 5.9 & 0.24 & 0.01 & 60.81 & 167.52 \\
\hline SD & 0.6 & 0.06 & - & 60.84 & 211.72 \\
\hline CV (\%) & 9.7 & 26.48 & 26.48 & 100.06 & 126.38 \\
\hline \multicolumn{6}{|l|}{ Potato } \\
\hline \multicolumn{6}{|c|}{ Banepa $\mathrm{M}^{\ddagger}$ Kavreplanchowk $(\mathrm{n}=219)$} \\
\hline Mean & 6.4 & 1.29 & 0.06 & 102.06 & 220.78 \\
\hline SD & 0.7 & 0.74 & 0.04 & 78.2 & 206.4 \\
\hline CV (\%) & 10.9 & 57.11 & 57.11 & 76.63 & 93.49 \\
\hline \multicolumn{6}{|l|}{ Maize } \\
\hline \multicolumn{6}{|c|}{ Nilkantha $\mathrm{M}^{\ddagger}$ Dhading $(\mathrm{n}=201)$} \\
\hline Mean & 6 & 1.6 & 0.08 & 37.24 & 207.76 \\
\hline SD & 0.5 & 0.81 & 0.04 & 57.07 & 182.11 \\
\hline CV (\%) & 8.7 & 50.56 & 50.56 & 153.23 & 87.65 \\
\hline \multicolumn{6}{|c|}{ Vegetable } \\
\hline \multicolumn{6}{|c|}{ Benighat Rarang $\mathrm{RM}^{\dagger}$ Dhading $(\mathrm{n}=143)$} \\
\hline Mean & 6.8 & 0.8 & 0.04 & 150.19 & 215.33 \\
\hline SD & 0.5 & 0.35 & 0.02 & 133.4 & 172.98 \\
\hline CV (\%) & 7.1 & 44.08 & 44.08 & 106.42 & 78.97 \\
\hline \multicolumn{6}{|c|}{ Gajuri $\mathrm{RM}^{\dagger}$ Dhading $(\mathrm{n}=109)$} \\
\hline Mean & 6.8 & 0.66 & 0.03 & 58.24 & 422.57 \\
\hline SD & 0.7 & 0.39 & 0.02 & 121.7 & 395.19 \\
\hline CV (\%) & 9.7 & 58.7 & 58.7 & 208.96 & 93.52 \\
\hline \multicolumn{6}{|c|}{ Dhunibesi $\mathrm{M}^{\ddagger}$ Dhading $(\mathrm{n}=101)$} \\
\hline Mean & 6.3 & 0.87 & 0.04 & 57.54 & 283.84 \\
\hline SD & 0.6 & 0.45 & 0.02 & 55.5 & 353.24 \\
\hline CV (\%) & 9.8 & 51.62 & 51.62 & 96.47 & 124.45 \\
\hline \multicolumn{6}{|c|}{ Bharatpur $\mathrm{Mp} \S$ Chitwan $(\mathrm{n}=241)$} \\
\hline Mean & 6.8 & 1.14 & 0.06 & 197.82 & 234.55 \\
\hline SD & 0.5 & 0.77 & 0.04 & 157.33 & 196.38 \\
\hline CV (\%) & 7.3 & 65.42 & 65.42 & 80.37 & 85.16 \\
\hline
\end{tabular}

+ Rural Municipality

₹ Municipality

$\S$ Metropolitan

I Organic matter, in \%

\# Total nitrogen, in \%

+t Available phosphorus, in $\mathrm{kg} \mathrm{ha}^{-1}$

\# Available potassium, in $\mathrm{kg} \mathrm{ha}^{-1}$ 
Table 4. Number of samples under different $\mathrm{pH}$ rating categories from soil-testing mobile van program in Nepal.

\begin{tabular}{|c|c|c|c|c|c|c|}
\hline & Alkaline & Neutral & Slightly acidic & Acidic & Highly acidic & Total \\
\hline \multicolumn{7}{|l|}{ Rice } \\
\hline Kechankebal RM ${ }^{\dagger}$, Jhapa & 1 & 5 & 71 & 125 & 17 & 219 \\
\hline Sunwal $\mathrm{M}^{\ddagger}$, Nawalparasi & 24 & 37 & 23 & 2 & - & 86 \\
\hline Sundari Haraincha $\mathrm{M}^{\ddagger}$, Morang & 3 & 25 & 12 & - & - & 40 \\
\hline Rupani $\mathrm{RM}^{\dagger}$, Saptari & - & 6 & 28 & 6 & - & 40 \\
\hline Inaruwa $\mathrm{M}^{\ddagger}$, Sunsari & 38 & 2 & - & - & - & 40 \\
\hline \multicolumn{7}{|l|}{ Potato } \\
\hline Banepa $\mathrm{M}^{\ddagger}$, Kavreplanchowk & 8 & 95 & 96 & 20 & - & 219 \\
\hline \multicolumn{7}{|l|}{ Maize } \\
\hline Nilkantha $\mathrm{M}^{\ddagger}$, Dhading & 40 & 59 & 83 & 19 & - & 201 \\
\hline \multicolumn{7}{|l|}{ Vegetable } \\
\hline Benighat Rarang $\mathrm{RM}^{\dagger}$, Dhading & 18 & 54 & 68 & 3 & - & 143 \\
\hline Gajuri $\mathrm{RM}^{\dagger}$, Dhading & 17 & 62 & 68 & 2 & - & 109 \\
\hline Dhunibesi $\mathrm{M}^{\ddagger}$, Dhading & 1 & 28 & 62 & 10 & - & 101 \\
\hline Bharatpur $\mathrm{Mp}^{\S}$, Chitwan & 14 & 171 & 55 & 1 & - & 241 \\
\hline Total & 164 & 544 & 566 & 188 & 17 & 1479 \\
\hline
\end{tabular}

+ Rural Municipality

₹ Municipality

$\S$ Metropolitan

source of carbon and $\mathrm{N}$ mineralization (Yeshaneh 2015). Intensive cropping observed in the study area (plantation of one to four crops within a year) has removed essential plant nutrients from the soil, thereby exerting pressure on soil fertility. Inclusion of legumes or cover crops in cropping system could be helpful in compensating for depletion of nutrients, compared with the addition of chemical fertilizers only. However, most of the farmers do not follow such a practice. Agricultural soils in these locations receive organic manure annually, which may improve soil fertility, minimize soil acidity, and favor plant growth. The present rate of organic manure application is far below the global average (Bishwakarma et al. 2014), which might not meet the crop demand on a long-term basis (Regmi 2000).

As OM decreases, so do total $\mathrm{N}$, available $\mathrm{P}_{2} \mathrm{O}_{5}$, available $\mathrm{K}_{2} \mathrm{O}$, and some micronutrients (Wang et al. 2006). Total $\mathrm{N}$ ranged from 0.01\% (in Sunsari district, rice zone) to $0.08 \%$ (in Dhading district, maize zone). Total $\mathrm{N}$ content was very low $(<0.05 \%)$ in more than half of the tested samples, which could be because of increased rate of mineralization and insufficient application of $\mathrm{N}$ fertilizer to nutrient-exhausting crops, such as wheat and maize (Goovaerts 1999). Available $\mathrm{P}_{2} \mathrm{O}_{5}$ ranged from $16.47 \mathrm{~kg} \mathrm{ha}^{-1}$ (in Saptari district, rice zone) to $197.82 \mathrm{~kg} \mathrm{ha}^{-1}$ (in Chitwan district, vegetable zone). The 
relatively higher availability of $\mathrm{P}_{2} \mathrm{O}_{5}$ observed as compared with $\mathrm{OM}$ and $\mathrm{N}$ could be caused by the dissolution of calcium-phosphorus under neutral soil reaction, as well as less erosion and runoff at that location (Pal, Wani, and Sahrawat 2012). Similarly, available $\mathrm{K}_{2} \mathrm{O}$ ranged from $84.3 \mathrm{~kg} \mathrm{ha}^{-1}$ (in Morang district, rice zone) to $422.57 \mathrm{~kg} \mathrm{ha}^{-1}$ (in Dhading district, vegetable zone). In general, soils in Terai region ranged from acidic to neutral $\mathrm{pH}$ among the selected locations. Of the total samples, 759 samples (53\%) were very low (OM: <1\% and $\mathrm{N}$ : <0.05) in OM and total N, 449 samples (31\%) were low in available $\mathrm{P}_{2} \mathrm{O}_{5}$, and 286 samples (45\%) were medium in available $\mathrm{K}_{2} \mathrm{O}$. Details regarding $\mathrm{pH}$ rating (alkaline, neutral, slightly acidic, acidic, and highly acidic) and nutrient values (very low, low, medium, high, and very high) are given in Tables $\mathbf{4}$ and $\mathbf{5}$ based on the number of soil samples from locations.

Table 5. Number of samples under different soil chemical nutrient rating categories from soil-testing mobile van program in Nepal.

\begin{tabular}{|c|c|c|c|c|c|}
\hline & Very low & Low & Medium & High & Very high \\
\hline \multicolumn{6}{|l|}{ Rice } \\
\hline \multicolumn{6}{|c|}{ Kechankebal $\mathrm{RM}^{\dagger}$, Jhapa $(\mathrm{n}=219)$} \\
\hline $\mathrm{OM}^{\pi}$ & 167 & 52 & - & - & - \\
\hline $\mathrm{N}^{\#}$ & 167 & 50 & 2 & - & - \\
\hline $\mathrm{P}_{2} \mathrm{O}_{5}^{+\dagger}$ & 25 & 107 & 37 & 36 & 14 \\
\hline $\mathrm{K}_{2} \mathrm{O}^{\ddagger \neq}$ & 23 & 68 & 106 & 15 & 7 \\
\hline \multicolumn{6}{|c|}{ Sunwal $M^{\ddagger}$, Nawalparasi $(n=86)$} \\
\hline $\mathrm{OM}^{\pi}$ & 21 & 43 & 22 & - & - \\
\hline $\mathrm{N}^{\#}$ & 21 & 39 & 24 & 2 & - \\
\hline $\mathrm{P}_{2} \mathrm{O}_{5}^{++}$ & 21 & 44 & 14 & 7 & - \\
\hline $\mathrm{K}_{2} \mathrm{O}^{\ddagger \neq}$ & 27 & 44 & 14 & 1 & - \\
\hline \multicolumn{6}{|c|}{ Sundari Haraincha $M^{\ddagger}$, Morang $(n=40)$} \\
\hline$O M^{\pi}$ & 1 & 34 & 5 & - & - \\
\hline $\mathrm{N}^{\#}$ & 1 & 25 & 14 & _- & - \\
\hline $\mathrm{P}_{2} \mathrm{O}_{5}^{++}$ & 1 & 2 & 18 & 16 & 3 \\
\hline $\mathrm{K}_{2} \mathrm{O}^{\ddagger \neq}$ & 4 & 32 & 3 & 1 & - \\
\hline \multicolumn{6}{|c|}{ Rupani $\mathrm{RM}^{\dagger}$, Saptari $(\mathrm{n}=40)$} \\
\hline OM" & 13 & 26 & 1 & - & - \\
\hline $\mathrm{N}^{\#}$ & 13 & 25 & 2 & - & - \\
\hline $\mathrm{P}_{2} \mathrm{O}_{5}^{+\dagger}$ & - & 38 & 1 & 1 & - \\
\hline $\mathrm{K}_{2} \mathrm{O}^{\ddagger \neq}$ & - & 5 & 35 & - & - \\
\hline \multicolumn{6}{|c|}{ Inaruwa $\mathrm{M}^{\ddagger}$, Sunsari $(\mathrm{n}=40)$} \\
\hline$O M^{\pi}$ & 40 & - & - & - & - \\
\hline $\mathrm{N}^{\#}$ & 40 & - & - & - & - \\
\hline $\mathrm{P}_{2} \mathrm{O}_{5}^{++}$ & - & 12 & 17 & 5 & 6 \\
\hline $\mathrm{K}_{2} \mathrm{O}^{\ddagger \neq}$ & 9 & 13 & 12 & 3 & 3 \\
\hline
\end{tabular}


Table 5 (continued). Number of samples under different soil chemical nutrient rating categories from soil-testing mobile van program in Nepal.

$$
\text { Verylow Low Medium High Very high }
$$

\section{Potato}

Banepa $\mathrm{M}^{\ddagger}$, Kavreplanchowk $(\mathrm{n}=219)$

$$
\begin{aligned}
& \mathrm{OM}^{\top} \\
& \mathrm{N}^{\#} \\
& \mathrm{P}_{2} \mathrm{O}_{5}^{++} \\
& \mathrm{K}_{2} \mathrm{O}^{\ddagger \neq}
\end{aligned}
$$

$\begin{array}{rrrrr}83 & 118 & 18 & - & - \\ 83 & 98 & 37 & 1 & - \\ 11 & 25 & 40 & 65 & 78 \\ 27 & 47 & 92 & 30 & 23\end{array}$

Maize

Nilkantha $\mathrm{M}^{\ddagger}$, Dhading $(\mathrm{n}=201)$

$$
\begin{aligned}
& \mathrm{OM}^{\top} \\
& \mathrm{N}^{\#} \\
& \mathrm{P}_{2} \mathrm{O}_{5}^{+\dagger} \\
& \mathrm{K}_{2} \mathrm{O}^{\ddagger \neq}
\end{aligned}
$$

$\begin{array}{rrrrr}43 & 127 & 31 & - & - \\ 43 & 98 & 59 & 1 & - \\ 22 & 111 & 31 & 29 & 8 \\ 10 & 53 & 96 & 29 & 13\end{array}$

\section{Vegetable}

Benighat Rarang $\mathrm{RM}^{\dagger}$, Dhading $(\mathrm{n}=143)$

OM

$\mathrm{N}^{\#}$

$\mathrm{P}_{2} \mathrm{O}_{5}{ }^{++}$

$\mathrm{K}_{2} \mathrm{O}^{\ddagger \neq}$

Gajuri $\mathrm{RM}^{\dagger}$, Dhading $(\mathrm{n}=109)$

$\mathrm{OM}^{\pi}$

$\mathrm{N}^{\#}$

$\mathrm{P}_{2} \mathrm{O}_{5}^{+\dagger}$

$\mathrm{K}_{2} \mathrm{O}^{\neq \neq}$

Dhunibesi $\mathrm{M}^{\ddagger}$, Dhading $(\mathrm{n}=101)$

$\mathrm{OM}^{\mathbb{T}}$

$\mathrm{N}^{\#}$

$\mathrm{P}_{2} \mathrm{O}_{5}{ }^{++}$

$\mathrm{K}_{2} \mathrm{O}^{\ddagger \neq}$

Bharatpur $\mathrm{Mp}^{\S}$, Chitwan $(\mathrm{n}=241)$

$\mathrm{OM}^{\mathbb{T}}$

$\mathrm{N}^{\#}$

$\mathrm{P}_{2} \mathrm{O}_{5}^{++}$

$\mathrm{K}_{2} \mathrm{O}^{\ddagger \neq}$

Total $(n=1479)$

$\mathrm{OM}^{\pi}$

$\mathrm{N}^{\#}$

$\mathrm{P}_{2} \mathrm{O}_{5}^{++}$

$\mathrm{K}_{2} \mathrm{O}^{\text {邦 }}$
105

105

20

7

$88 \quad 21$

$88 \quad 20$

31

2

$62 \quad 39$

$\begin{array}{ll}62 & 37\end{array}$

$5 \quad 35$

1

9

759

759

137

128
38
38

31

29

25

7

97

$\begin{array}{ll}97 & 7\end{array}$

87

19

25

13

17

147

$595 \quad 83$

$517 \quad 153$

449

345
8
13

+ Rural Municipality

₹ Municipality

$\S$ Metropolitan

I Organic matter, in \%

\# Total nitrogen, in \%

++ Available phosphorus, in $\mathrm{kg} \mathrm{ha}^{-1}$

\# Available potassium, in $\mathrm{kg} \mathrm{ha}^{-1}$ 


\section{Nutrient indexing of soil chemical parameters}

Nutrient indices were calculated to determine the status of OM, total $\mathrm{N}$, available $\mathrm{P}_{2} \mathrm{O}_{5}$, and available $\mathrm{K}_{2} \mathrm{O}$ at the district level on the basis of the commodity for block, zone, or superzone. There was a sharp decrease in OM and total $\mathrm{N}$ in all districts, ranging from 1 to 1.27 and 1 to 1.35 respectively, representing low nutrient indices (Table 6). The available $\mathrm{P}_{2} \mathrm{O}$ ranged from low (in Jhapa, Nawalparasi, Sunsari, and Dhading districts) to high (in Morang, Kavreplanchowk and Chitwan districts) nutrient indices; whereas, available $\mathrm{K}_{2} \mathrm{O}$ ranged from low (in Nawalparasi, Morang and Saptari districts) to medium (in Jhapa, Sunsari, Kavreplanchowk, Dhading, and Chitwan districts) nutrient indices (Table 6). In general, soil nutrient indices, which were at low or medium levels, would need a relatively higher amount of fertilizer application than those at a high level. However, nutrient management for sustained crop growth and yield should be focused on OM management, as it is closely associated with soil macro- and micro-nutrients.

\section{Fertilizer recommendations}

The soil-health report and fertilizer recommendations sheet included all information provided by farmers for the identification of soil samples. The

Table 6. District-wide nutrient indices for different agro block, zone and superzone from soiltesting mobile van program in Nepal.

\begin{tabular}{|c|c|c|c|c|c|c|c|c|}
\hline & \multicolumn{2}{|l|}{$O M^{+}$} & \multicolumn{2}{|l|}{$N^{\ddagger}$} & \multicolumn{2}{|l|}{$\mathrm{P}_{2} \mathrm{O}_{5}{ }^{\S}$} & \multicolumn{2}{|l|}{$K_{2} O^{\pi}$} \\
\hline & Value & Remark & Value & Remark & Value & Remark & Value & Remark \\
\hline \multicolumn{9}{|l|}{ Rice } \\
\hline Jhapa & 1 & Low & 1.01 & Low & 1.63 & Low & 1.68 & Medium \\
\hline Nawalparasi & 1.27 & Low & 1.34 & Low & 1.33 & Low & 1.19 & Low \\
\hline Morang & 1.13 & Low & 1.35 & Low & 2.4 & High & 1.13 & Low \\
\hline Saptari & 1 & Low & 1 & Low & 1.98 & Medium & 1.6 & Low \\
\hline Sunsari & 1.02 & Low & 1.05 & Low & 1.08 & Low & 1.88 & Medium \\
\hline \multicolumn{9}{|l|}{ Potato } \\
\hline $\begin{array}{l}\text { Kavreplanchowk } \\
\text { Maize }\end{array}$ & 1.08 & Low & 1.18 & Low & 2.49 & High & 1.9 & Medium \\
\hline Dhading & 1.15 & Low & 1.3 & Low & 1.52 & Low & 1.9 & Medium \\
\hline \multicolumn{9}{|l|}{ Vegetable } \\
\hline Dhading & 1 & Low & 1.01 & Low & 2.01 & Medium & 2.14 & Medium \\
\hline Chitwan & 1.04 & Low & 1.1 & Low & 2.76 & High & 2.11 & Medium \\
\hline
\end{tabular}

+ Organic matter

₹ Total nitrogen

$\S$ Available phosphorus

I Available potassium 
recommendations sheet has two parts: the soil-health status based on previously grown crop and fertilizer recommendation for the crop to be grown. Soil tests are most commonly used to predict the likelihood of crop yield responses to inputs of fertilizers and lime. However, Nepalese farmers have scant knowledge of soil physico-chemical properties, which is necessary to develop yield goals across different cropping systems. Fertilizer calculations are often excluded and application rates are adjusted on the basis of climate and soil properties at a specific location.

The recommendations sheet provides additional information about the method of fertilizer application; for example, a half dose of recommended nitrogenous fertilizer, full dose of the phosphatic and potassic fertilizers to be applied as a basal dose, and the remainder half dose of nitrogenous fertilizer as split application per crop type. For Nepalese farmers, the most commonly recommended chemical fertilizers by SMD were urea ( $46 \%$ nitrogen) and/or ammonium sulfate (21\% nitrogen and $26 \%$ sulfur) as nitrogenous sources, di-ammonium phosphate (18\% nitrogen and $46 \%$ phosphorus) as a phosphatic source, and muriate of potash $(60 \%$ potassium and $40 \%$ chlorine) or potassium sulfate ( 40 to $44 \%$ of potassium and $18 \%$ of sulfur) as potassic sources. In addition, farmers were encouraged to apply agricultural lime to ameliorate acidic soils, at least $2-3$ weeks before planting time (NARC 2013). Details about soil pH range and recommended agricultural lime rate are given in Table 7. Similarly, recommended doses of chemical fertilizers for specific crops are given in Table 8. Because of the small farm size, which is common in Nepal, recommendations are made in $\mathrm{kg}_{\text {ropani }}{ }^{-1}$, where 20 ropani $=1$ hectare.

Table 7. Recommended dose of agricultural lime for Mid-hills and Terai region of Nepal.

\begin{tabular}{|c|c|c|c|c|c|c|}
\hline \multirow[b]{2}{*}{$p H$} & \multicolumn{3}{|c|}{ Mid-hills (kg ropani-1) } & \multicolumn{3}{|c|}{ Terai $\left(\mathrm{kg} \mathrm{ropani}^{-1}\right)$} \\
\hline & Sandy loam & Loam & Clay & Sandy loam & Loam & Clay \\
\hline 5.9 & 85 & 110 & 146 & 45 & 62 & 128 \\
\hline 5.8 & 97 & 128 & 166 & 52 & 72 & 146 \\
\hline 5.7 & 108 & 142 & 188 & 58 & 82 & 166 \\
\hline 5.6 & 119 & 158 & 208 & 64 & 90 & 184 \\
\hline 5.5 & 130 & 170 & 230 & 70 & 100 & 200 \\
\hline 5.4 & 140 & 188 & 252 & 76 & 110 & 220 \\
\hline 5.3 & 150 & 204 & 274 & 81 & 118 & 238 \\
\hline 5.2 & 160 & 218 & 294 & 86 & 126 & 254 \\
\hline 5.1 & 169 & 228 & 314 & 91 & 136 & 270 \\
\hline 5 & 176 & 240 & 334 & 96 & 142 & 286 \\
\hline 4.9 & 184 & 252 & 354 & 101 & 150 & 302 \\
\hline 4.8 & 191 & 262 & 374 & 106 & 158 & 316 \\
\hline 4.7 & 199 & 272 & 390 & 111 & 166 & 330 \\
\hline 4.6 & 205 & 280 & 406 & 115 & 174 & 350 \\
\hline 4.5 & 210 & 290 & 420 & 120 & 180 & 360 \\
\hline
\end{tabular}


Table 8. Recommendation of nutrient according to the soil-testing and crop to be grown in Nepal.

\begin{tabular}{|c|c|c|c|c|c|c|c|c|c|}
\hline \multirow{3}{*}{$\frac{\text { Crop }}{\text { Rice (irrigated) }}$} & \multicolumn{3}{|c|}{$\begin{array}{c}\text { Nitrogen } \\
\left(k^{\prime} \text { ropani }{ }^{-1}\right) \\
\text { Nutrient Status }\end{array}$} & \multicolumn{3}{|c|}{$\begin{array}{c}\text { Phosphorus } \\
\text { (kg ropani }^{-1} \text { ) } \\
\text { Nutrient Status }\end{array}$} & \multicolumn{3}{|c|}{$\begin{array}{c}\text { Potash } \\
\left(\mathrm{kg} \text { ropani }^{-1}\right) \\
\text { Nutrient Status }\end{array}$} \\
\hline & \multicolumn{2}{|c|}{ Low Medium } & \multirow{2}{*}{$\begin{array}{r}\text { High } \\
1.25\end{array}$} & \multicolumn{2}{|c|}{ Low Medium } & \multirow{2}{*}{$\begin{array}{r}\text { High } \\
0.38\end{array}$} & \multicolumn{2}{|c|}{ Low Medium } & \multirow{2}{*}{$\begin{array}{l}\text { High } \\
0.38\end{array}$} \\
\hline & 5 & 2.5 & & 1.5 & 0.75 & & 1.5 & 0.75 & \\
\hline Rice (rainfed) & 3 & 1.5 & 0.75 & 1 & 0.5 & 0.25 & 1 & 0.5 & 0.25 \\
\hline Maize (rainy season) & 3 & 1.5 & 0.75 & 1.5 & 0.75 & 0.38 & 1.5 & 0.75 & 0.38 \\
\hline Maize (winter season) & 4.5 & 2.25 & 1.13 & 2.25 & 1.13 & 0.56 & 2.25 & 1.13 & 0.56 \\
\hline Potato & 11 & 5.5 & 2.75 & 7 & 3.5 & 1.75 & 5 & 2.5 & 1.25 \\
\hline Vegetables (leafy) & 10 & 5 & 2.5 & 9 & 4.5 & 2.25 & 4 & 2 & 1 \\
\hline Vegetables (root) & 10 & 5 & 2.5 & 9 & 4.5 & 2.25 & 4 & 2 & 1 \\
\hline Green pea & 0.75 & 0.38 & 0.19 & 2 & 1 & 0.5 & 6 & 3 & 1.5 \\
\hline Cucumber & 7 & 3.5 & 1.75 & 2 & 1 & 0.5 & 5 & 2.5 & 1.25 \\
\hline Summer squash & 12 & 6 & 3 & 9 & 4.5 & 2.25 & 3 & 1.5 & 0.75 \\
\hline Tomato (Srijana variety) & ) 10 & 5 & 2.5 & 9 & 4.5 & 2.25 & 4 & 2 & 1 \\
\hline Tomato (dwarf variety) & 10 & 5 & 2.5 & 10 & 5 & 2.5 & 7.5 & 3.75 & 1.88 \\
\hline Brinjal & 10 & 5 & 2.5 & 9 & 4.5 & 2.25 & 4 & 2 & 1 \\
\hline Lady's finger (okra) & 10 & 5 & 2.5 & 9 & 4.5 & 2.25 & 3 & 1.5 & 0.75 \\
\hline Cauliflower (local) & 10 & 5 & 2.5 & 6 & 3 & 1.5 & 4 & 2 & 1 \\
\hline Cauliflower (hybrid) & 10 & 5 & 2.5 & 6 & 3 & 1.5 & 5 & 2.5 & 1.25 \\
\hline Cabbage & 12 & 6 & 3 & 9 & 4.5 & 2.25 & 4 & 2 & 1 \\
\hline Bean & 4 & 2 & 1 & 6 & 3 & 1.5 & 3 & 1.5 & 0.75 \\
\hline Bitter gourd & 10 & 5 & 2.5 & 6 & 3 & 1.5 & 3 & 1.5 & 0.75 \\
\hline Cowpea & 4 & 2 & 1 & 6 & 3 & 1.5 & 2 & 1 & 0.5 \\
\hline Bell pepper & 10 & 5 & 2.5 & 5 & 2.5 & 1.25 & 5 & 2.5 & 1.25 \\
\hline Onion & 12 & 6 & 3 & 9 & 4.5 & 2.25 & 4 & 2 & 1 \\
\hline
\end{tabular}

\section{Conclusion}

In general, the results from mobile lab analysis of 1,479 farmers' soil samples in eight different districts of Nepal revealed that the majority of samples had very low to low $\mathrm{OM}$ and total $\mathrm{N}$, low to very high available $\mathrm{P}_{2} \mathrm{O}_{5}$, and low to high available $\mathrm{K}_{2} \mathrm{O}$ contents. Similarly, the majority of samples represented slightly acidic to neutral soil pH. After analysis, for each crop to be grown, farmers were provided with individual soil health reports and fertilizer recommendations (rate, amount, and type). Based on the criteria for calculating nutrient index, soils in the study area were characterized as low for OM and total $\mathrm{N}$, low to high for available $\mathrm{P}_{2} \mathrm{O}_{5}$, and low to medium for available $\mathrm{K}_{2} \mathrm{O}$. This study showed that the soil-testing mobile van programs would be a successful way to transfer technology for soil improvement by connecting scientists and farmers. 
Acknowledgments - The authors acknowledge Soil Management Directorate, Ministry of Agricultural Development, Nepal for conducting this program. Special thanks to all the team members of soil-testing campaigns conducted in all the location used in this study. Last but not the least, our sincere thanks to Bharat Sharma Acharya, Nikita Bhusal, Clint Beiermann, and Bikesh Twanabasu for their technical support during the preparation of the manuscript.

\section{References}

Balla, M. K., K. R. Tiwari, G. Kafle, S. Gautam, S. Thapa, and B. Basnet. 2014. Farmers' dependency on forests for nutrients transfer to farmlands in mid-hills and high mountain regions in Nepal (case studies in Hemja, Kaski, Lete and Kunjo, Mustang district). International Journal of Biodiversity and Conservation 6 (3):222-29. doi:10.5897/IJBC2013.0670

Bishwakarma, B. K., N. R. Dahal, R. Allen, N. P. Rajbhandari, B. K. Dhital, D. B. Gurung, and I. C. Baillie. 2014. Effects of improved management and quality of farmyard manure on soil organic carbon contents in small-holder farming systems of the middle hills of Nepal. Climate and Development 7 (5):426-36. doi:10.1080/1756552 9.2014.966045

Bremner, D. C., and J. M. Mulvaney. 1982. Total nitrogen. In Methods of soil analysis, eds. A. L. Miller, R. H. Miller, and D. R. Keaney, Vol. 9, Issue 2. Madison, WI: American Society of Agronomy.

Gazey, C., and S. Davies. 2009. Soil acidity: A guide for Western Australia farmers and consultants. Department of Agriculture and Food, Western Australia Bulletin, Western Australia, Perth, 4784.

Ghimire, D., and D. Panday. 2017. Interconnection of climate change, agriculture and climate justice: Complexities for feeding the world under changing climate. Development 59 (4). doi:10.1057/s41301-017-0118-5

Ghimire, R., and P. Bista. 2016. Crop diversification improves $\mathrm{pH}$ in acidic soils. Journal of Crop Improvement 30 (6):657-67. doi:10.1080/15427528.2016.1219894

Goovaerts, P. 1999. Geostatistics in soil science: State-of-the-art and perspectives. Geoderma 89 (1-2):1-45. doi:10.1016/So016-7061(98)ooo78-o

Jackson, M. L. 1973. Soil chemical analysis. New Delhi: Prentice Hall of India Pvt. Ltd.

Maharjan, K. L., and N. P. Joshi. 2013. Climate change, agriculture and rural livelihoods in developing countries. Tokyo: Springer Japan.

Marx, E. S., J. Hart, and R. G. Stevens. 1999. Soil test interpretation guide. EC 1478. Corvallis, OR: Oregon State University Extension.

NARC. 2013. The objectives of soil test and methods to take sampling for test (in Nepali). Lalitpur, Nepal: Nepal Agricultural Research Council Extension Fact Sheet. Soil Science Division.

Olsen, S. R., C. V. Cole, F. S. Watanabe, and L. A. Dean. 1954. Estimation of available phosphorus in soils by extraction with sodium bicarbonate. U. S. Department of Agriculture Circular No. 939. Banderis, A. D., D. H. Barter and K. Anderson. Agricultural and Advisor, Washington. 
Pal, D. K., S. P. Wani, and K. L. Sahrawat. 2012. Vertisols of tropical Indian environments: Pedology and edaphology. Geoderma 189-190:28-49. doi:10.1016/j. geoderma.2012.04.021

Panday, D. 2012. Adapting climate change in agriculture: The sustainable way in Nepalese context. Hydro Nepal Special Issue: Conference Proceedings. 91-94.

Paudel, B., B. S. Acharya, R. Ghimire, K. R. Dahal, and P. Bista. 2014. Adapting agriculture to climate change and variability in Chitwan: Long-term trends and farmers' perceptions. Agricultural Research 3:165-74. doi:10.1007/ s40003-014-0103-o

Ramamurthy, B., and J. C. Bajaj. 1969. Available nitrogen, phosphorus and potassium status of Indian soils. Fertilizer News 14:25-36.

Regmi, A. P. 200o. Effects of long term application of mineral fertilizers and manure on rice-rice-wheat system. [Online] Accessed July 14, 2017. http://libcatalog. cimmyt.org/download/cim/67242.pdf

Rijal, S. P. 2001. Soil fertility decline in Nepal: Problem and strategy. Nepal Journal of Science and Technology 3:41-36.

Rosen, C., P. Bierman, and R. Eliason. 2008. Soil test interpretations and fertilizer management for lawns, turf, gardens, and landscape plants. BU-01731. University of Minnesota-Extension Service, St Paul, MN.

Schreier, H., S. Brown, and P. B. Shah. 1995. Identification of key resource issues: Discussions and recommendations. In Challenges in mountain resources management in Nepal: Processes, trends and dynamics in middle mountain watershed, eds. H. Schreier, P. B. Shah, and S. Brown. Proceedings of a Workshop, held in Kathmandu, 10-12 April 1995, pp 183-192. Kathmandu: ICIMOD.

Sharma, K. C. 2001. Crop diversification in Nepal. In Crop diversification in the AsiaPacific region, Expert Consultation, held in Thailand, FAO Regional office for Asia and the Pacific, Bangkok, Thailand, eds. M. K. Papademetriou, and F. J. Dent.

Toth, S. J., and A. L. Prince. 1949. Estimation of CEC and exchangeable Ca, K, and Na content of soil by Flame photometer technique. Soil Science 67:439-45. doi:10.1097/00010694-194906000-00003

Walkley, A., and I. A. Black. 1934. An examination of the Degtjareff method for determining organic carbon in soils: Effect of variations in digestion conditions and of inorganic soil constituents. Soil Science 63:251-63. doi:10.1097/00010694-194704000-00001

Wang, J., H. Raman, G. Zhang, N. Mendham, and M. Zou. 20o6. Aluminium tolerance in barely (Horidium vulgarie L.): Physiological mechanisms, genetics and screening methods. Journal of Zhejiang University Science 7:769-87. doi:10.1631/jzus.2006. Bo769

WBG. 2017. The World Bank Group. Fertilizer consumption (kilograms per hectare of arable land). [Online] Accessed June 3, 2017. http://data.worldbank.org/indicator/ AG.CON.FERT.ZS

Yeshaneh, G. T. 2015. Assessment of micronutrient status in different land use soils in Maybar lake watershed of Albuko district, South Wello zone, North Ethiopia. Global Journal of Crop, Soil Science and Plant Breeding 3 (1):143-50. 